Molecular characterization of Miraflores peach variety and relatives using SSRs

M. Bouhadida ${ }^{1}$, A.M. Casas $^{2}$, M.A. Moreno ${ }^{1} \&$ Y. Gogorcena ${ }^{1}$

${ }^{1}$ Department of Pomology; ${ }^{2}$ Department of Genetics and Plant Production, Aula Dei Experimental Station, CSIC, P.O. Box 202, E-50080-Zaragoza, Spain

\begin{abstract}
Some traditional peach varieties, originated from the region of Aragón (Spain), were analysed by SSRs (Simple Sequence Repeats). The aim of this research was to characterize 19 clones related to 'Miraflores' variety, with unknown pedigrees, to assess their genetic diversity and to elucidate their possible relationships with 10 traditional peach varieties. Twenty SSR primer pairs with high levels of polymorphism, which have been previously developed for peach, were used in this study. A total of 46 alleles were obtained for all the microsatellites studied, ranging from one to six alleles per locus, with a mean value of 2.3 alleles per locus. Fourteen SSRs were polymorphic in the set of varieties studied and permitted to distinguish 16 different genotypes out of the 30 initially studied, although fourteen 'Miraflores' clones showed identical gel profiles. The genetic distance matrix was used to construct Neighbor joining cluster and to perform principal coordinate analysis which allowed the arrangement of all the genotypes according to their genetic relationships. The genetic relationships among these traditional peach varieties, and in particular among 'Miraflores' clones are discussed. The obtained results confirm that microsatellite markers are very useful for these purposes.
\end{abstract}

Keywords: Clones, Genetic diversity, Genetic relationships, Microsatellites, 'Miraflores' peach variety, Traditional peach varieties 


\section{3-1. INTRODUCTION}

Peach [Prunus persica (L.) Batsch] is a member of the Rosaceae, and it is a diploid species with a basic chromosome number of $x=8$ and $2 n=16$. The Prunus persica is thought to be originated in China and spread to the rest of the world by means of seeds (Layne, 1987). It is a species well adapted to temperate and subtropical regions, between latitudes of $30^{\circ}$ and $45^{\circ}$ North and South (Westwood, 1978). The EU (European Union) is one of the main cultivation regions, with approximately 4.5 million metric tons annual production of peaches and nectarines $(28 \%$ of the world production). The four countries: Italy, Spain, Greece, and France, ensure $92.7 \%$ of this production (FAOSTAT, 2005), Italy being the greatest peach producer of them $(1,750,000$ metric tons) followed by Spain (1,130,800 metric tons). Peach is one of the most economically and socially important deciduous fruit tree species. Therefore, precise cultivar identification and characterisation is essential for improving and securing peach culture in the world.

The official methods used to characterize and identify varieties in fruit tree species are based on morphological characterization and phenological observations according to UPOV (Unité pour la Protection des Obtentions Végétales) and IPGRI (International Plant Genetic Resources Institute) descriptors. This approach requires time, and the morphological characters can be subject to environmental influences. New molecular methods have been incorporated to characterize the varieties at the DNA level (see for a review: Martínez-Gómez et al., 2003). Molecular markers such as restriction fragment length polymorphism (RFLP), random amplified polymorphic DNA (RAPD) and amplified fragment length polymorphism (AFLP) have been used for genetic analysis and the construction of genetic linkage maps (Gogorcena et al., 1993; Warburton and Bliss, 1996; Ortiz et al., 1997; Bartolozzi et al., 1998; De Vicente et al., 1998; Casas et al., 1999). On the downside, these DNA markers either present low reproducibility (RAPDs), or are time consuming and expensive (RFLPs, AFLPs). In the last years, microsatellite markers (SSR) are becoming the appropriate marker for molecular characterization and genetic diversity studies (Fang and Roose, 1997; Alvarez et al., 2001; Huang et al., 2002; Rallo et al., 2003; Moussaoui, 2005). Consisting of tandem repeats of mono-, bi-, tri- or tetra-nucleotides in the eukaryotic genome, these molecular markers present a very high polymorphism based on the number of the nucleotide motif repeats (Morgante and Olivieri, 1993). Besides 
polymorphism, they have a codominant inheritance, they are reproducible and easily detected by PCR. Microsatellite marker primer pairs have been developed in peach (Sosinski et al., 2000; Testolin et al., 2000; Aranzana et al., 2002; Dirlewanger et al., 2002), and then used in genetic diversity analyses for sweet cherry (Dirlewanger et al., 2002), peach (Aranzana et al., 2003), and apricot (Romero et al., 2003; Zhebentyayeva et al., 2003).

'Miraflores' is a Spanish native peach variety, with attractive characteristics, especially high yields and good quality of fruits (Moreno, 2005). This nonmelting and clingstone variety is widely used for the fresh market as well as for processing. This variety appeared in 1970's at the Jalón valley (Aragón), one of the most important deciduous fruit tree growing areas in Spain. 'Miraflores' has unknown parents, although it is believed that it could originate from 'Campiel' seedlings, a traditional variety locally cultivated in this area (De Asso, 1798). The correct molecular characterization of this variety should prevent all confusion with other varieties with similar morphological characteristics, and enhance its use in peach breeding programs. On the other hand, this will be useful to warrant this variety as a specific typical product with a designation of origin.

Therefore, the aim of this study was to characterize nineteen clones of 'Miraflores' peach variety with unknown pedigree, using 20 SSR primer pairs. Ten old Spanish peach varieties originated from the same region were also included in this investigation, to check genetic similarities and possible genetic relationships with 'Miraflores'.

\section{3-2. MATERIALS AND METHODS}

\section{3-2-1. Plant material}

Thirty peach accessions, being either clones of 'Miraflores' or closely related varieties with other traditional peach varieties were collected throughout Aragón, and were analysed in this study. Nineteen accessions (clones and/or closely related varieties) were provided from a recent survey of 'Miraflores' variety ('Miraflores' 1 to 19). The other eleven accessions are old Spanish peach varieties originated from the same region of Aragón (Spain); two clones of 'Tipo Campiel' variety ('Tipo 
Campiel 1' and 'Tipo Campiel 2') and nine traditional cultivars ('Amarillo de Calanda', 'Zaragozano Amarillo', 'Amarillo de Gallur', 'Tardío del Pilar', 'Oropel', 'Zaragozano Rojo', 'Maluenda', 'Bonet IV', 'Amarillo de Septiembre'). From all accessions, young leaves were collected for DNA extraction.

\section{3-2-2. Genomic DNA extraction}

Fresh young leaves were ground to powder with liquid $\mathrm{N}_{2}$ using a mortar and pestle. Genomic DNA was isolated from leaf samples using a CTAB (cethyltrimethyl ammonium bromide) extraction method (Cheng et al., 1997). The extraction buffer contained 2\% CTAB, 1.5 M NaCl, $20 \mathrm{mM}$ EDTA, $100 \mathrm{mM}$ Tris $\mathrm{pH}$ 8.0, and 0.4\% 2mercaptoethanol. Samples were incubated at $65^{\circ} \mathrm{C}$ for approximately $30-60 \mathrm{~min}$, mixed with an equal volume of chloroform-isoamyl alcohol (24:1), and centrifuged at $13,000 \mathrm{rpm}$ for $10 \mathrm{~min}$ at room temperature. The supernatant was transferred to a clean microcentrifuge tube and treated with RNAse A $\left(10 \mathrm{mg} / \mathrm{ml}, 60 \mathrm{~min}, 37^{\circ} \mathrm{C}\right)$, then mixed with an equal volume of cold isopropanol. The DNA was pelleted by centrifugation at 13,000 rpm for 3-5 min. The supernatant was removed and the DNA pellet washed with $500 \mu \mathrm{l}$ of $70 \%$ ethanol and $50 \mu \mathrm{l}$ of wash buffer (3 M sodium acetate, $0.1 \mathrm{M}$ magnesium acetate, $\mathrm{pH} 8.0$ ), to remove residual CTAB, salt, and other contaminants. The pellet was dried for $1 \mathrm{~h}$ and then dissolved in $100 \mu \mathrm{l}$ of TE buffer (10 mM Tris-HCl, $0.1 \mathrm{mM}$ EDTA, $\mathrm{pH}$ 8.0). DNA quality was examined by electrophoresis in $0.8 \%$ agarose and DNA concentration was quantified spectrophotometrically (Gene Quant, Amersham Pharmacia Biotech). The extracted DNA was diluted to $5 \mathrm{ng} / \mu \mathrm{l}$ with $\mathrm{TE}$ buffer and stored at $-20^{\circ} \mathrm{C}$ for $\mathrm{PCR}$ amplifications.

\section{3-2-3. DNA amplification}

Twenty SSR markers were studied (Table 3-1) using primer pairs previously developed for peach. Amplification reactions were carried out in a final volume of 15 $\mu \mathrm{l}$ containing $10 \mathrm{ng}$ of template DNA, $1 \mathrm{X}$ reaction buffer $\left(20 \mathrm{mM}\left(\mathrm{NH}_{4}\right)_{2} \mathrm{SO}_{4}, 75 \mathrm{mM}\right.$ Tris- $\mathrm{HCl} \mathrm{pH} 8.8), 2 \mathrm{mM} \mathrm{MgCl} 2,0.2 \mathrm{mM}$ of dNTPs $(50 \mu \mathrm{M}$ of each) (Amersham Pharmacia Biotech), $0.15 \mu \mathrm{M}$ of forward and reverse primers each, and $0.5 \mathrm{U}$ of Tth

DNA Polymerase (Biotools B and M Labs, S.A., Spain), overlaid with a drop of 
mineral oil (Sigma, St Louis, MO). The PCR amplifications were carried out on a Gene Amp 2700 thermocycler (Applied Biosystems) using the following temperature cycles: 1 cycle of $3 \mathrm{~min}$ at $95^{\circ} \mathrm{C}, 35$ cycles of $1 \mathrm{~min}$ at $94^{\circ} \mathrm{C}, 45 \mathrm{~s}$ at the corresponding annealing temperature (Table 3-1) and $1 \mathrm{~min}$ at $72^{\circ} \mathrm{C}$. The last cycle was followed by a final incubation for $7 \mathrm{~min}$ at $72^{\circ} \mathrm{C}$ and the PCR products were stored at $4^{\circ} \mathrm{C}$ before analysis. Two independent SSR reactions were performed for each DNA sample. The DNA amplification products were loaded on 5\% polyacrilamide sequencing gels. Gels were run for $2 \mathrm{~h}$ at $65 \mathrm{~W}$. The gels were silver-stained according to the protocol described by Bassam et al. (1983). Fragment sizes were estimated with the 30-330 bp AFLP ladder (Invitrogen, Carlsbad, Calif.) DNA sizing markers, and analysed by the Quantity One program (Bio Rad, Hercules, CA).

\section{3-2-4. Data analysis}

The number of alleles per locus was counted from the gel profile analysis. The observed heterozygosity (Ho) was calculated for each locus as the number of heterozygous individuals over the total number of individuals analysed. The expected heterozygosity was calculated as $\mathrm{He}=1-\Sigma \mathrm{p}_{\mathrm{i}}{ }^{2}$, where $\mathrm{p}_{\mathrm{i}}$ is the frequency of $\mathrm{i}^{\text {th }}$ allele (Nei, 1973). The power of discrimination was calculated as PD $=1-\Sigma \mathrm{g}_{\mathrm{i}}{ }^{2}$, where $\mathrm{g}_{\mathrm{i}}$ is the frequency of $i^{\text {th }}$ genotype (Kloosterman et al., 1993). Those parameters served to evaluate the information given by the microsatellite markers (Table 3-1).

Data were analyzed using the NTSYS-pc, version 2.1 program (Rohlf, 2000). A 0/0.5/1 (absence/allele in heterozygosity/allele in homozygosity) matrix was constructed. The genetic distances between pairs of varieties were estimated from the matrix with the SIMGEND module using the Nei coefficient (Nei, 1972). Cluster analyses were carried out using Neighbor Joining (NJ) algorithm (Saitou and Nei, 1987). The resulting cluster was represented as a dendrogram. A principal coordinate analysis based on the similarity matrix was also performed.

\section{3-3. RESULTS}

\section{3-3-1. Microsatellite diversity}


Spanish peach varieties were analysed with 20 SSRs. All the SSRs studied were single-locus and produced alleles that could be scored, with a total of 46 ranging from one to six per locus, with a mean value of 2.3 alleles per locus. Fourteen out of the 20 SSRs employed, were polymorphic and it was possible to distinguish unambiguously 16 peach genotypes from the 30 accessions studied. However, six SSR loci (СРРСТ002, СРРСТ005, СРРСТ017, СРРСТ030, UDP98-408 and ВРPCT007) were monomorphic for the peach plant material evaluated (Table 3-1). Observed heterozygosity (Ho) ranged from 0 to 0.70 in CPPCT006, with a mean value of 0.18 . The expected heterozygosity $(\mathrm{He})$ ranged from 0 , for the monomorphic SSRs, to 0.67 in BPPCT008, with a mean value of 0.29. The power of discrimination (PD) varied from 0 , for the monomorphic loci, to 0.67 in ВРPCT008, with an average value of 0.31. Differences were found in the number of genotypes identified per locus. This number varied between one unique genotype in the monomorphic loci, to 8 genotypes using BPPCT008 with a mean value of 2.75 (Table 3-1).

The five most polymorphic microsatellites were CPPCT028, UDP98-022, BPPCT001, ВРPCT008, and ВРРCT015 (Table 3-1), most of them showed the highest He and PD. These SSRs allowed the unambiguous discrimination of the same 16 accessions separated using all the SSRs studied. These five SSR primer pairs detected a total of 21 alleles, ranging from 3 to 6 alleles per locus and with a mean value of 4.2 alleles per locus. The expected heterozygosity mean value for these microsatellites was $\mathrm{He}=0.53$, and the power of discrimination mean value was $\mathrm{PD}=$ 0.54 . 
Table 3-1. List of the 20 SSR primers used in this study, size range, annealing temperature, number of alleles and variability parameters.

\begin{tabular}{|c|c|c|c|c|c|c|c|c|}
\hline Locus code & References & $\begin{array}{l}\text { Size range } \\
\text { (bp) }\end{array}$ & Ta $\left({ }^{\circ} \mathrm{C}\right)$ & $\mathbf{N}$ & Ho & He & \#Genotypes & PD \\
\hline СРРСТ002 & Aranzana et al. 2002 & 102 & $58^{\circ} \mathrm{C}$ & 1 & 0.00 & 0.00 & 1 & 0.00 \\
\hline СРРСТ004 & Aranzana et al. 2002 & $262-277$ & $56^{\circ} \mathrm{C}$ & 2 & 0.03 & 0.10 & 2 & 0.13 \\
\hline СРРСТ005 & Aranzana et al. 2002 & 154 & $58^{\circ} \mathrm{C}$ & 1 & 0.00 & 0.00 & 1 & 0.00 \\
\hline СРРСТ006 & Aranzana et al. 2002 & $182-192$ & $60^{\circ} \mathrm{C}$ & 2 & 0.70 & 0.52 & 3 & 0.46 \\
\hline СРРСТ017 & Aranzana et al. 2002 & 183 & $60^{\circ} \mathrm{C}$ & 1 & 0.00 & 0.00 & 1 & 0.00 \\
\hline СРРСТ022 & Aranzana et al. 2002 & $248-292$ & $58^{\circ} \mathrm{C}$ & 3 & 0.00 & 0.13 & 3 & 0.13 \\
\hline СРРСТ028 & Aranzana et al. 2002 & $134-138$ & $58^{\circ} \mathrm{C}$ & 3 & 0.00 & 0.35 & 3 & 0.35 \\
\hline СРРСТ029 & Aranzana et al. 2002 & $192-196$ & $58^{\circ} \mathrm{C}$ & 2 & 0.00 & 0.43 & 2 & 0.43 \\
\hline СРРСТ030 & Aranzana et al. 2002 & 186 & $56^{\circ} \mathrm{C}$ & 1 & 0.00 & 0.00 & 1 & 0.00 \\
\hline СРРСТ033 & Aranzana et al. 2002 & $151-153$ & $58^{\circ} \mathrm{C}$ & 2 & 0.10 & 0.09 & 2 & 0.18 \\
\hline ВРРСТ001 & Dirlewanger et al. 2002 & $152-166$ & $60^{\circ} \mathrm{C}$ & 6 & 0.03 & 0.62 & 7 & 0.63 \\
\hline ВРРСТ007 & Dirlewanger et al. 2002 & 146 & $58^{\circ} \mathrm{C}$ & 1 & 0.00 & 0.00 & 1 & 0.00 \\
\hline ВРРСТ008 & Dirlewanger et al. 2002 & $100-156$ & $59^{\circ} \mathrm{C}$ & 4 & 0.67 & 0.67 & 8 & 0.67 \\
\hline ВРРСТ015 & Dirlewanger et al. 2002 & $168-222$ & $62^{\circ} \mathrm{C}$ & 5 & 0.03 & 0.50 & 6 & 0.52 \\
\hline ВРРСТ017 & Dirlewanger et al. 2002 & $162-174$ & $60^{\circ} \mathrm{C}$ & 2 & 0.57 & 0.54 & 2 & 0.57 \\
\hline ВРРСТ038 & Dirlewanger et al. 2002 & $127-129$ & $62^{\circ} \mathrm{C}$ & 2 & 0.67 & 0.45 & 2 & 0.45 \\
\hline UDP98-022 & Testolin et al. 2000 & $124-138$ & $64^{\circ} \mathrm{C}$ & 3 & 0.00 & 0.52 & 3 & 0.52 \\
\hline UDP98-025 & Testolin et al. 2000 & $134-142$ & $65^{\circ} \mathrm{C}$ & 2 & 0.13 & 0.44 & 3 & 0.54 \\
\hline UDP98-407 & Testolin et al. 2000 & $174-198$ & $60^{\circ} \mathrm{C}$ & 2 & 0.57 & 0.40 & 3 & 0.59 \\
\hline UDP98-408 & Testolin et al. 2000 & 102 & $56^{\circ} \mathrm{C}$ & 1 & 0.00 & 0.00 & 1 & 0.00 \\
\hline Mean & & & & 2.3 & 0,18 & 0.29 & 2.75 & 0.31 \\
\hline
\end{tabular}

Ta: annealing temperature; N: number of alleles; Ho: observed heterozygosity; He: expected heterozygosity; \# Genotypes: different genotypes per locus; and PD: power of discrimination.

\section{3-3-2. Cluster and principal coordinate analysis}

The genetic distance (D) among the different genotypes studied using the 20 SSRs was reproduced in the Neighbor Joining (NJ) dendrogram (Figure 3-1), according to the original data obtained in the similarity matrix, and based on the additive genetic distances among the genotypes (Saitou and Nei, 1987).

The dendrogram generated from the NJ cluster analysis showed two main groups. The first group was composed of the two 'Tipo Campiel' clones, 'Tardío del Pilar', 'Amarillo de Septiembre' and all the 'Miraflores' clones but 'Miraflores 3', which was clustered out of the two main groups. The second group included the rest of the studied varieties. In the first group, fourteen 'Miraflores' clones ('Miraflores' 5 to 11 and 'Miraflores' 13 to 19) were clustered together with a null genetic distance among them. The 'Miraflores 1' and 'Miraflores 2' were closely related to the fourteen 
indistinguishable 'Miraflores' clones with a genetic distance $\mathrm{D}=0.07$ and $\mathrm{D}=0.12$, respectively. However, 'Miraflores 4' and 'Miraflores 12' were clustered further away,

at a genetic distance of $\mathrm{D}=0.26$ and $\mathrm{D}=0.21$, respectively. The two 'Tipo Campiel' clones were genetically identical with the 20 SSRs, and 'Miraflores 4' was closely related to them with a small genetic distance of $\mathrm{D}=0.04$.

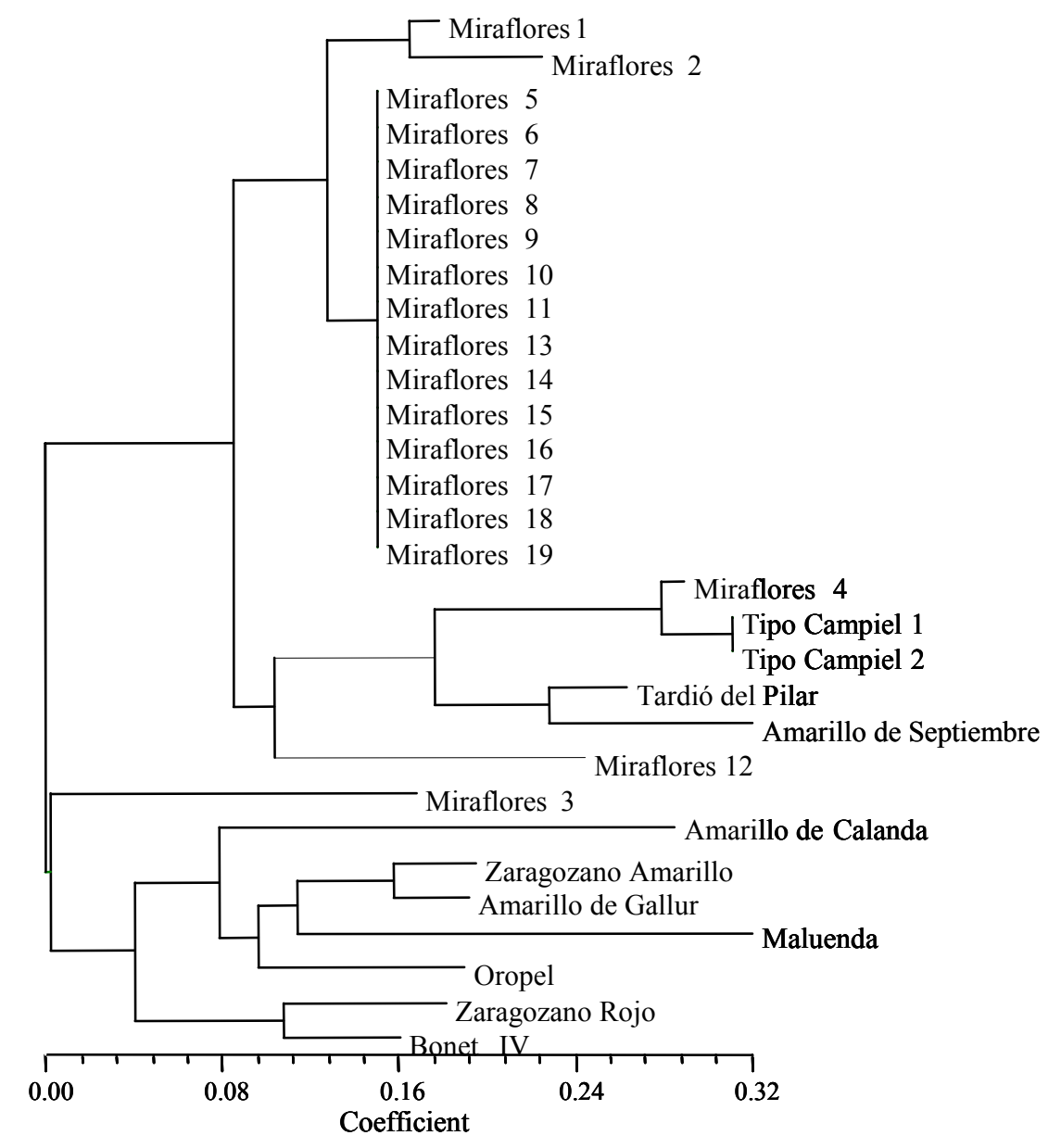

Figure 3-1. Dendrogram of the 30 peach accessions obtained from the Neighbor Joining analysis (NJ) using Nei's genetic distance (1972) after amplification with 20 SSR primer pairs.

The Principal Coordinate Analysis (PCA) generated two clearly significant components, which explained $44 \%$ and $32 \%$ of the total variance (Figure $3-2$ ). This analysis showed well defined distribution patterns of the accessions, according to the 
genetic distances and the relationships among them. In the PCA, two main groups could be clearly seen, the first one was composed by 'Amarillo de Septiembre', 'Tardío del Pilar' and all the 'Miraflores' clones but 'Miraflores 3' and 'Miraflores 4'. The second group included the varieties 'Oropel', 'Amarillo de Gallur', 'Zaragozano Amarillo' and 'Amarillo de Calanda'. Again, the PCA showed the small distance between the 'Miraflores 4' and the two 'Tipo Campiel' clones. The 'Miraflores 3' appeared further away from all the 'Miraflores' clones.

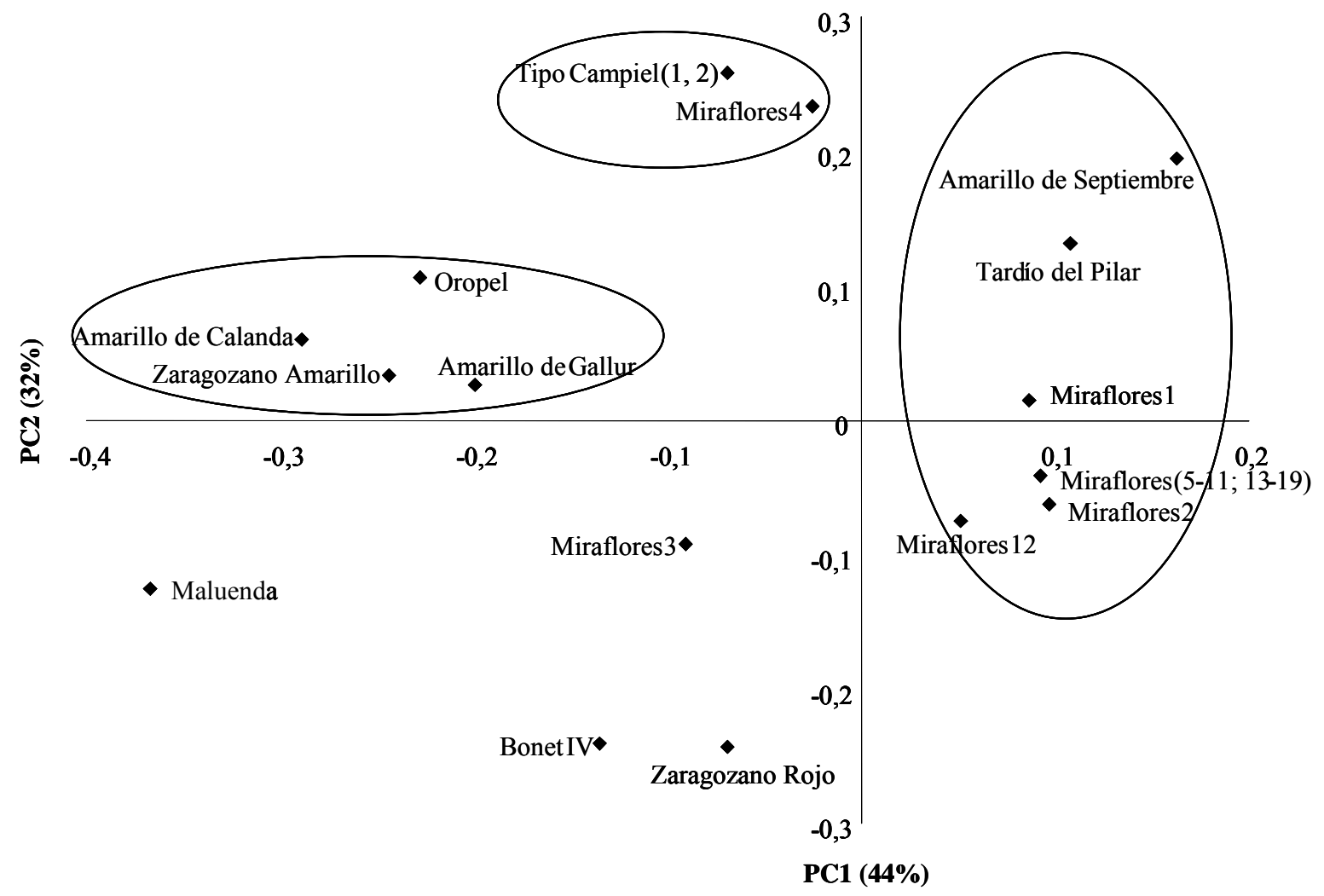

Figure 3-2. Plot of the first two components (PC1 and PC2) of the principal coordinate analysis on the similarity matrix for 30 peach accessions (varieties and related clones) using 20 SSRs. 


\section{3-4. DISCUSSION}

\section{3-4-1. Genetic diversity}

The 20 SSR loci produced between 1 to 6 alleles with a mean value of 2.3 alleles per locus. This mean value calculated with 30 peach accessions, was lower than the mean values obtained by other authors in this species. Testolin et al. (2000) mentioned a value of 4.5 for a set of 50 varieties analysed with 26 microsatellites. Aranzana et al. (2002) cited 3.2 for a set of 25 varieties with 24 SSRs, and Dirlewanger et al. (2002) observed 4.2 for a set of 27 varieties with 41 SSR primer pairs. Mean values for the expected heterozygosity $(\mathrm{He})$ and for the power of discrimination (PD) were also lower than the values recorded by these authors. In the present study, the He and PD were 0.29 and 0.31 , respectively. Testolin et al. (2000) mentioned $\mathrm{He}=0.47$ and $\mathrm{PD}=$ 0.60; Aranzana et al. (2002) found value of 0.41 for $\mathrm{He}$, and 0.60 for $\mathrm{PD}$, and Dirlewanger et al. (2002) reported values of 0.41 for He, and 0.54 for PD. These results indicate a low variability in our plant material that can be explained by the close genetic relationship among the peach accessions studied and in particular, among the 'Miraflores' clones. However, using only the five most polymorphic primer pairs (ВРPCT001, ВРPCT008, ВРPCT015, UDP98-022, and СРPCT028), the mean value of alleles per locus increased to 4.2. An increase in the mean values of the expected heterozygosity $(\mathrm{He}=0.53)$ and the power of discrimination $(\mathrm{PD}=0.54)$ has also been shown. These new values are closer to the ones mentioned by Testolin et al. (2000), Aranzana et al. (2002) and Dirlewanger et al. (2002). The high levels of polymorphism in the selected five SSRs, permitted to distinguish unambiguously 16 genotypes within the thirty studied accessions, the same genotypes that were discriminated using all the twenty SSR primers pairs. Thus, those five polymorphic SSRs are interesting markers for studies aimed at distinguishing highly related peach varieties. The fourteen clones of 'Miraflores' showed identical patterns for all the SSRs used in this study. These clones either belong to the same clone or represent different clones that differ by a single or few gene mutations, which could not be detected by SSR analysis (Testolin et al., 2000). 


\section{3-4-2. Cultivar relationships from cluster and principal coordinate analysis}

The fourteen 'Miraflores' clones showed identical SSR profiles and were clustered together in the NJ tree. These clones have also similar pomological characteristics (M.A. Moreno, unpublished observation). The genetic similarity among some 'Miraflores' clones was also shown in a preliminary study reported by Moreno and Casas (2002) using 10 SSRs and 7 RAPDs. In terms of genetic distance, the 'Miraflores 1' and 'Miraflores 2' were closely related with the group of the fourteen identical 'Miraflores' clones with a genetic distance of 0.07 and 0.12 , respectively. These two clones differed from the 'Miraflores' main group in only two SSR loci. The 'Miraflores 1' had a new allele with +2 bp in the locus UDP98-022 (138 bp) and the lack of the allele $174 \mathrm{bp}$ in the locus BPPCT017. The 'Miraflores 2' had a new allele with +2 bp in the locus UDP98-022 (138 bp) and a new allele with +2 bp in the locus CPPCT028 (136 bp). These two clones presented also similar Rosaceae flower shape, the same flowering and ripening date, and similar yield and fruit characteristics with the group of identical 'Miraflores' clones. The small molecular discrepancies of these two clones from the main group of 'Miraflores' may have been caused by SSR mutations as it was also suggested by Aranzana et al. (2003).

The 'Miraflores 12' is closer to the 'Miraflores' group ('Miraflores' 5-11 and 1319) than to the old Spanish varieties at a genetic distance of $D=0.21$. Moreover, this clone shared at least one allele in 17 SSR loci (34 alleles out of the 40 studied) with the group of identical 'Miraflores' clones. These results point out the existence of a close parental relationships between these clones and we can suggest that 'Miraflores 12 ' could be one of the 'Miraflores' progenitors. 'Miraflores 4' was clustered to the identical 'Miraflores' group at a genetic distance of $\mathrm{D}=0.26$. This clone is closely related to the two identical 'Tipo Campiel' clones at a genetic distance of $\mathrm{D}=0.04$. 'Miraflores 4' had at least one common allele in all SSR loci with the 'Tipo Campiel' clones and shared 37 alleles of the total alleles studied. According to the morphological data (data not shown), 'Miraflores 4' presents similar fruit characteristics to 'Tipo Campiel' cultivar (high percentage of redness in the skin), and similar flower morphology (bell flower shape). Moreover, the pulp close to the stone of the fruit is red as in the 'Tipo Campiel' fruits. Our findings confirm the hypothesis reported previously by Moreno and Casas (2002) that 'Miraflores 4' could be a seedling of 'Tipo Campiel' cultivar. 
Finally, 'Miraflores 3' was clustered out of the two main groups shown in the NJ tree, at a genetic distance of $\mathrm{D}=0.40$. Furthermore, 'Miraflores 3' showed chemical and physical characteristics different from the rest of 'Miraflores' clones (fruit shape, yellow-red skin appearance, early ripening, sugar and acids content, etc.). This clone probably belongs to another variety which has morphological and phenological characteristics similar to those of 'Miraflores' variety. Previous work pointed out that this clone could be the 'Godina 58GC76' variety, based on similarities in fruit characteristics (fruit color, fruit shape, sugar and acid level etc.) (M.A. Moreno, unpublished observation).

The 'Miraflores' clones studied in this work have unknown parents and pedigrees. Old spanish varieties were included in the study to check an eventual relationship with 'Miraflores' clones. As it is shown in the dendrogram (Figure 3-1), and the PCA (Figure 3-2), the varieties 'Tardío del Pilar', 'Amarillo de Septiembre', 'Tipo Campiel' and all of the 'Miraflores' clones, but 'Miraflores 3', belong to the same group. The varieties 'Tardío del Pilar', 'Amarillo de Septiembre', and 'Tipo Campiel' were related to the 'Miraflores' clones at the genetic distances of 0.24, 0.30 and 0.31, respectively. In fact, these varieties, showed similar physical fruit characteristics (properties of the pulp and skin appearance) to those found in 'Miraflores' clones. Thus, we hypothesise that they could be close relatives of 'Miraflores' cultivar. However, the rest of the old Spanish varieties ('Amarillo de Calanda', 'Zaragozano Amarillo', 'Amarillo de Gallur', 'Oropel', 'Zaragozano Rojo', 'Maluenda' and 'Bonet IV'), were clustered in another main group far away from the 'Miraflores' clones.

In this work, the absence of SSR differences among fourteen clones of 'Miraflores' could be explained by the usual clonal propagation of 'Miraflores' carried out by nurseries and fruit growers. Another possibility could be that these clones may represent the original genotype of 'Miraflores' with few genetic variations such as sport mutations. However by using SSRs, it is highly improbable to distinguish mutants that differ from the original genotype in one or few genes (Botta et al., 1995; Moreno et al., 1998; Aranzana et al., 2003).

In conclusion, we regard the clones (1, 2, 5-11 and 13-19) of 'Miraflores' as true clones of the 'Miraflores' variety, and they will be included in future programs of selection. While 'Miraflores 12' was considered as one of the 'Miraflores' progenitors and 'Miraflores 4' could be considered as a new cultivar, closely related to 'Tipo Campiel'. 'Miraflores 3' is considered unrelated to the main group of 
'Miraflores'. These studies make possible the adequate choice of clones and varieties in new crosses for selection purposes.

\section{ACKNOWLEDGMENTS}

We are thankful to T.N. Zhebentyayeva and G.L. Reighard for helpful comments on the manuscript. This research was funded by CICYT (Comisión Interministerial de Ciencia y Tecnología, AGL2002-04219 and AGL 2005-05533), INIA (Instituto Nacional de Investigación y Tecnología Agraria y Alimentación, RF03-014-C2), Bilateral Spain-France (HF03-273) and DGA (A28, A44) projects and co-funded by the European Regional Development Fund. M. Bouhadida was supported by a fellowship from the AECI (Agencia Española de Cooperación Internacional) of the Spanish Ministry of Foreign Affairs.

\section{REFERENCES}

Alvarez, A.E., Van de Wiel, C.C.M., Smulders, M.J.M. and Vosman, B. 2001. Use of microsatellites to evaluate genetic diversity and species relationships in the genus Lycopersicon. Theor. Appl. Genet. 103: 1283-1292.

Aranzana, M.J., García-Mas, J., Carbó, J. and Arús, P. 2002. Development and variability analysis of microsatellite markers in peach. Plant Breed.121: 87-92.

Aranzana, M.J., Carbó, J. and Arús, P. 2003. Microsatellite variability in peach [Prunus persica (L.) Batsch]: cultivar identification, marker mutation, pedigree inferences and population structure. Theor. Appl. Genet. 106: 1341-1352.

Bartolozzi, F., Warburton, M.L., Arulsekar, S. and Gradziel, T.M. 1998. Genetic characterization and relatedness among California almond cultivars and breeding lines detected by randomly amplified polymorphic DNA (RAPD) analysis. J. Amer. Soc. Hort. Sci. 123: 381-387.

Bassam, B.J., Caetano-Anoelles, G. and Gresshoff, P.M. 1983. Fast and sensitive silver staining of DNA in polyacrylamide gels. Anal. Biochem. 196: 80-83.

Botta, R., Scott, N.S., Eynard, I. and Thomas, M.R. 1995. Evaluation of microsatellite sequence-tagged site markers for characterizing Vitis vinifera cultivars. Vitis 2: 99-102.

Casas, A.M., Igartua, E., Balaguer, G. and Moreno, MA. 1999. Genetic diversity of Prunus rootstocks analysed by RAPD markers. Euphytica 110: 139-149. 
Cheng, F.S., Brown, S.K. and Weeden, N.F. 1997. A DNA extraction protocol from various tissues in woody species. Hort. Sci. 32: 921-922.

De Asso, D.I. 1798. Historia de la economía política de Aragón. Francisco Magallón, Zaragoza, $487 \mathrm{pp}$.

De Vicente, M.C., Truco, M.J., Egea, J., Burgos, L. and Arús, P. 1998. RFLP variability in apricot (Prunus armeniaca L.). Plant Breeding 117: 153-158.

Dirlewanger, E., Cosson, P., Tavaud, M., Aranzana, M.J., Poizat, C., Zanetto, A., Arús, P. and Laigret, F. 2002. Development of microsatellite markers in peach [Prunus persica (L.) Batsch] and their use in genetic diversity analysis in peach and sweet cherry (Prunus avium L.). Theor. Appl. Genet. 105: 127-138.

Fang, D.Q. and Roose, M.L. 1997. Identification of closely related citrus cultivars with inter-simple sequence repeat markers. Theor. Appl. Genet. 95: 408-417.

Faostat. 2005. Agricultural data.http://faostat.fao.org/faostat/

Gogorcena, Y., Arulsekar, S., Dandekar, A.M. and Parfitt, D.E. 1993. Molecular markers for grape characterization. Vitis 32: 183-185.

Huang, X., Börner, A., Röder, M. and Ganal, M. 2002. Assessing genetic diversity of wheat (Triticum aestivum L.) germplasm using microsatellite markers. Theor. Appl. Genet. 105: 699-707.

Kloosterman, A.D., Budowle, B. and Daselaar, P. 1993. PCR-amplification and detection of the human DIS80 VNTR locus. Amplification conditions, population genetics and application in forensic analysis. Int. J. Leg. Med. 105: 257-264.

Layne, R.E.C. 1987. Peach rootstocks. In: R.C. Rom and R.F. Carlson (Eds), Rootstocks for Fruit Crops, John Wiley and Sons, NY, pp. 185-216.

Martínez-Gómez, P., Sozzi, G.O., Sánchez-Pérez, R., Rubio, M. and Gradziel, T.M. 2003. New approaches to Prunus tree crop breeding. Food, Agriculture and Environment 1: 52-63.

Moreno, M.A. 2005. Selección de patrones y variedades de melocotonero adaptados a condiciones del área mediterránea. Vida Rural 206: 28-31.

Moreno, M.A. and Casas, A.M. 2002. Selección de variedades autóctonas de melocotonero. Actas de Horticultura 34: 741-746.

Moreno, S., Martín, J.P. and Ortiz, J.M. 1998. Inter-simple sequence repeats PCR for characterization of closely related grapevine germplasm. Euphytica 101: 117-125.

Morgante, M. and Olivieri, A.M. 1993. PCR-amplified microsatellites as markers in plant genetics. Plant J. 3: 175-182. 
Moussaoui, S. 2005. Molecular Characterization of Grapevine Cultivars from Aragón Gene Bank Using Sequence-Tagged Microsatellite Site Markers. Master of Science Thesis, IAMZ, Spain.

Nei, M. 1972. Genetic distance between populations. Am. Nat. 106: 283-292.

Nei, M. 1973. Analysis of gene diversity in subdivided populations. Proc. Natl. Acad. Soc. USA 70: 3321-3323.

Ortiz, A., Renaud, R., Calzada, I. and Ritter, E. 1997. Analysis of plum cultivars with RAPD markers. J. Hort. Sci.72: 1-9.

Rallo, P., Tenzer, I., Gessler, C., Baldón, L., Dorado, G. and Martín, A. 2003. Transferability of olive microsatellite loci across the genus Olea. Theor. Appl. Genet. 107: 940-946.

Rohlf, F.J. 2000. NTSYS-pc Numerical Taxonomy and Multivariate Analysis System. Version 2.1. Exeter Software, Setauket, NY.

Romero, C., Pedryc, A., Muñoz, V., Llácer, G. and Badenes, M.L. 2003. Genetic diversity of different apricot geographical groups determined by SSR markers. Genome 46: 244-252.

Saitou, N. and Nei, M. 1987. The neighbor-joining method: a new method for reconstructing phylogenetic trees. Mol. Biol. Evol. 4: 477-491.

Sosinski, B., Gannavarapu, M., Hager, L.D., Beck, L.E., King, G.J., Ryder, C.D., Rajapakse, S., Baird, W.V., Ballard, R.E. and Abbot A.G. 2000. Characterization of microsatellite in peach [Prunus persica (L.) Batsch]. Theor. Appl. Genet. 97: 1034-1041.

Testolin, R., Marrazo, T., Cipriani, G., Quarta, R., Verde, I., Dettori, M.T., Pancaldi, M. and Sansavini, S. 2000. Microsatellite DNA in peach (Prunus persica L. Batsch) and its use in fingerprinting and testing the genetic origin of cultivars. Genome 43: 512-520.

Warburton, M.L. and Bliss, F.A. 1996. Genetic diversity in peach (Prunus persica L. Batsch) revealed by randomly amplified polymorphic DNA (RAPD) markers and compared to inbreeding coefficients. J. Amer. Soc. Hort. Sci. 121: 1012-1019.

Westwood, M.N. 1978. Temperature Zone Pomology. Freeman, San Francisco, 428 pp.

Zhebentyayeva, T.N., Reighard, G.L., Gorina, V.M. and Abbot, A.G. 2003. Simple sequence repeat (SSR) analysis for assessment of genetic variability in apricot germplasm. Theor. Appl. Genet. 106: 435-444. 